\title{
Isolated cerebellar damage caused by carbon monoxide intoxication
}

\author{
Salih Hamcan, ${ }^{1}$ Veysel Akgun, ${ }^{2}$ Omer Yilmaz, ${ }^{3}$ Aynur Turan ${ }^{4}$
}

'Department of Radiology, Balıkesir Military Hospital, Balıkesir, Turkey ${ }^{2}$ Department of Radiology, Gulhane Military Medical Academy, Ankara, Turkey ${ }^{3}$ Department of Radiology, Suleyman Demirel University Faculty of Medicine, Isparta, Turkey

${ }^{4}$ Department of Radiology, Etlik Training and Research Hospital, Ankara, Turkey

\section{Correspondence to}

Dr Veysel Akgun,

akgunveysel@yahoo.com
CrossMark

To cite: Hamcan $S$,

Akgun V, Yilmaz 0 , et al. BMJ Case Rep Published online: [please include Day Month Year] doi:10.1136/ bcr-2013-201647

\section{DESCRIPTION}

An unconscious 5-year-old girl with convulsions was admitted to emergency department. Her blood carboxyhaemoglobin level was 7.3\%. CO intoxication was presumed and she was referred to our department for a brain MRI. In addition to conventional sequences, diffusion-weighted imaging (DWI) was also performed.

Whereas there was no pathological signal change on supratentorial images, symmetrical lesions in the grey matter were observed in both cerebellar hemispheres. MRI showed hypointensities on T1weighted image (figure 1A), hyperintensities both on T2-weighted image (figure 1B) and fluid-attenuated inversion recovery image in these
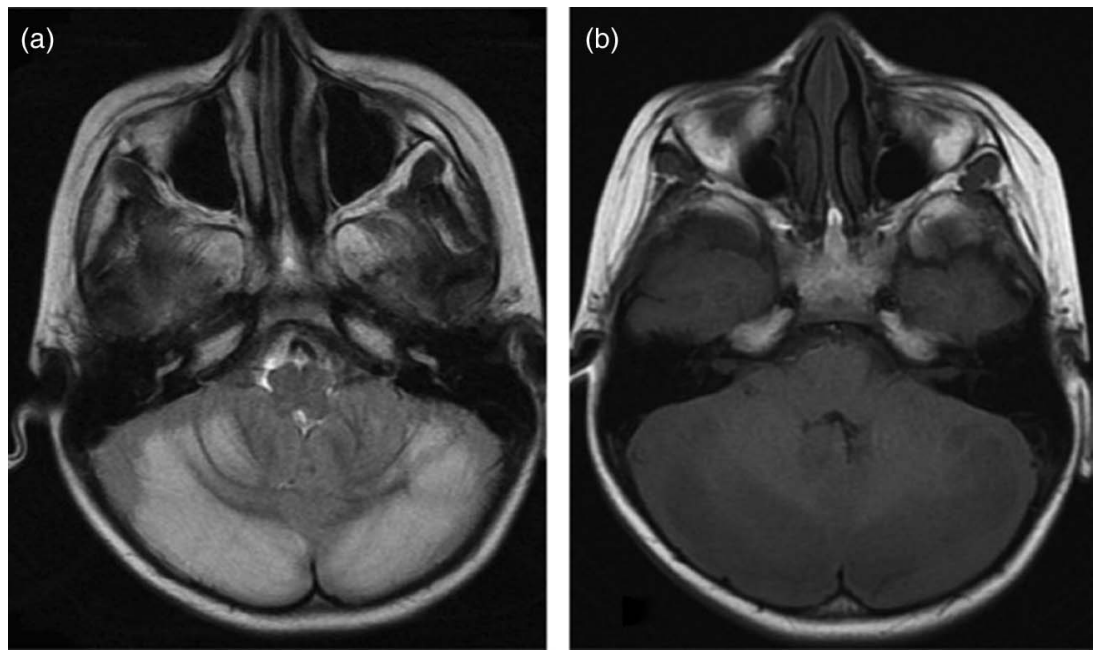

Figure 1 Axial T2-weighted image (A) showing hyperintense and T1WI (B) showing hypointense lesions in grey matter of the both cerebellar hemispheres.
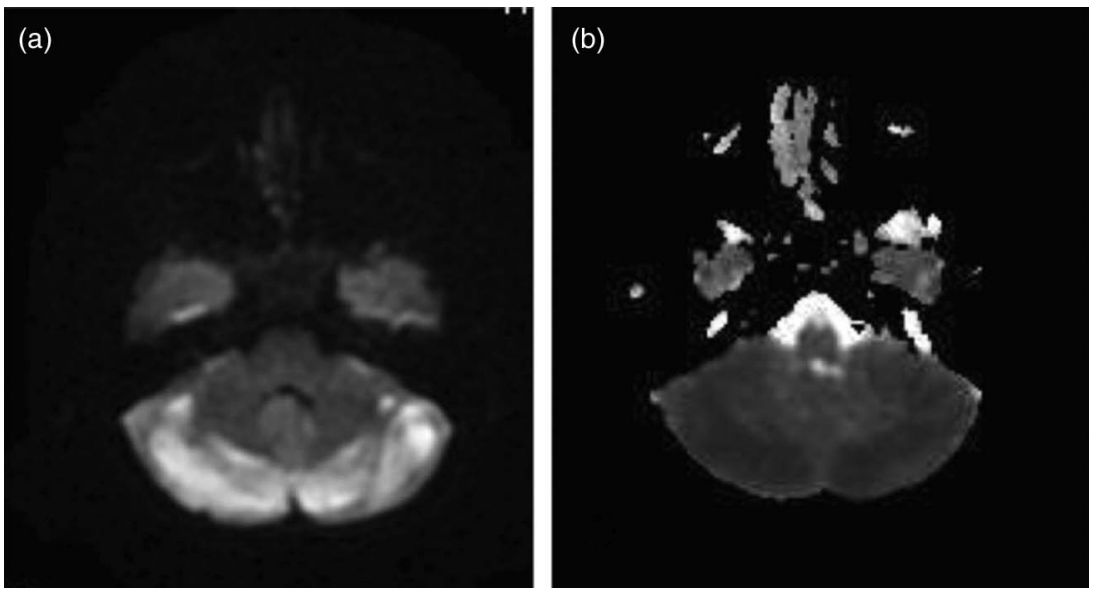

Figure 2 In both cerebellar hemispheres hyperintensity on diffusion-weighted imaging (A) and hypointensity on apparent diffusion coefficient (ADC) maping (B) compatible with diffusion restriction due to early ischaemia. affected areas. A diffusion-weighted MRI revealed restricted diffusion pattern due to cytotoxic oedema (figure $2 \mathrm{~A}, \mathrm{~B}$ ) as well. As a result, $\mathrm{CO}$ intoxication with isolated cerebellar damage was confirmed as the final diagnosis based on these MRI findings.

$\mathrm{CO}$ is a highly toxic gas affecting predominantly the central nervous system. Clinical features of poisoning are generally non-specific and its severity ranges from mild headache to death depending on the concentration of the exposed gas and exposure duration. In CO poisoning, as is in other hypoxic ischaemic central nervous system events, relatively poor vascularisation and 'watershed' areas are more vulnerable and affected earlier. ${ }^{1}$ The most sensitive 
brain regions to hypoxia are the cerebral cortex, white matter, basal ganglia and Purkinje cells in the cerebellum. ${ }^{2}$ The lesions identified in the MRI are commonly located in supratentorial region and cerebellar lesions often coincide with supratentorial ones. However, isolated cerebellar lesions without supratentorial involvement may be the only MRI findings in CO poisoning.

\section{Learning points}

- In CO poisoning, as is in other hypoxic ischaemic central nervous system events, relatively poor vascularisation and 'watershed' areas are more vulnerable and affected earlier. The most sensitive brain regions to hypoxia are the cerebral cortex, white matter, basal ganglia and Purkinje cells in the cerebellum.

- In MRI, cerebellar lesions usually coincide with supratentorial ones. However, isolated cerebellar lesions may be the only MRI findings in $\mathrm{CO}$ poisoning.
Competing interests None.

Patient consent Obtained.

Provenance and peer review Not commissioned; externally peer reviewed.

\section{REFERENCES}

1 Prockop LD, Chichkova RI. Carbon monoxide intoxication: an updated review. J Neurol Sci 2007;262:122-30.

2 Mascalchi M, Petruzzi P, Zampa V. MRI of cerebellar white matter damage due to carbon monoxide poisoning: case report. Neuroradiology 1996;38(Suppl 1): s73-4.

Copyright 2013 BMJ Publishing Group. All rights reserved. For permission to reuse any of this content visit http://group.bmj.com/group/rights-licensing/permissions.

BMJ Case Report Fellows may re-use this article for personal use and teaching without any further permission.

Become a Fellow of BMJ Case Reports today and you can:

- Submit as many cases as you like

- Enjoy fast sympathetic peer review and rapid publication of accepted articles

- Access all the published articles

- Re-use any of the published material for personal use and teaching without further permission

For information on Institutional Fellowships contact consortiasales@bmjgroup.com

Visit casereports.bmj.com for more articles like this and to become a Fellow 